\title{
RESEARCH
}

Open Access

\section{Protein kinase C-delta inhibition protects blood-brain barrier from sepsis-induced vascular damage}

\author{
Yuan Tang ${ }^{1}$, Fariborz Soroush', Shuang Sun², Elisabetta Liverani', Jordan C. Langston', Qingliang Yang ${ }^{1}$,
} Laurie E. Kilpatrick ${ }^{2}$ and Mohammad F. Kiani ${ }^{1,4^{*}}$

\begin{abstract}
Background: Neuroinflammation often develops in sepsis leading to activation of cerebral endothelium, increased permeability of the blood-brain barrier (BBB), and neutrophil infiltration. We have identified protein kinase C-delta (PKC $)$ as a critical regulator of the inflammatory response and demonstrated that pharmacologic inhibition of PKC $\delta$ by a peptide inhibitor (PKC $\delta-i)$ protected endothelial cells, decreased sepsis-mediated neutrophil influx into the lung, and prevented tissue damage. The objective of this study was to elucidate the regulation and relative contribution of PKC $\delta$ in the control of individual steps in neuroinflammation during sepsis.
\end{abstract}

Methods: The role of PKC $\delta$ in mediating human brain microvascular endothelial (HBMVEC) permeability, junctional protein expression, and leukocyte adhesion and migration was investigated in vitro using our novel BBB on-a-chip $\left(B^{3} C\right)$ microfluidic assay and in vivo in a rat model of sepsis induced by cecal ligation and puncture (CLP). HBMVEC were cultured under flow in the vascular channels of $\mathrm{B}^{3} \mathrm{C}$. Confocal imaging and staining were used to confirm tight junction and lumen formation. Confluent HBMVEC were pretreated with TNF-a $(10 \mathrm{U} / \mathrm{ml})$ for $4 \mathrm{~h}$ in the absence or presence of PKC $\delta-i(5 \mu \mathrm{M})$ to quantify neutrophil adhesion and migration in the $\mathrm{B}^{3} \mathrm{C}$. Permeability was measured using a 40-kDa fluorescent dextran in vitro and Evans blue dye in vivo.

Results: During sepsis, PKC $\delta$ is activated in the rat brain resulting in membrane translocation, a step that is attenuated by treatment with PKC $-i$. Similarly, TNF-a-mediated activation of PKC $\delta$ and its translocation in HBMVEC are attenuated by PKC $\delta-i$ in vitro. PKC $\delta$ inhibition significantly reduced TNF-a-mediated hyperpermeability and TEER decrease in vitro in activated HBMVEC and rat brain in vivo $24 \mathrm{~h}$ after CLP induced sepsis. TNF-a-treated HBMVEC showed interrupted tight junction expression, whereas continuous expression of tight junction protein was observed in non-treated or PKC $\delta-i$-treated cells. PKC $\delta$ inhibition also reduced TNF-a-mediated neutrophil adhesion and migration across HBMVEC in $B^{3} C$. Interestingly, while PKC $\delta$ inhibition decreased the number of adherent neutrophils to baseline (no-treatment group), it significantly reduced the number of migrated neutrophils below the baseline, suggesting a critical role of PKC $\delta$ in regulating neutrophil transmigration.

Conclusions: The BBB on-a-chip $\left(B^{3} C\right)$ in vitro assay is suitable for the study of BBB function as well as screening of novel therapeutics in real-time. PKC $\delta$ activation is a key signaling event that alters the structural and functional integrity of BBB leading to vascular damage and inflammation-induced tissue damage. PKC $\delta$-TAT peptide inhibitor has therapeutic potential for the prevention or reduction of cerebrovascular injury in sepsis-induced vascular damage.

Keywords: Blood-brain barrier, Protein kinase C-delta, Microvascular endothelial cells, Microfluidic assay, Sepsis, Neuroinflammation

\footnotetext{
* Correspondence: mkiani@temple.edu

'Department of Mechanical Engineering, College of Engineering, Temple University, Philadelphia, PA 19122, USA

${ }^{4}$ Department of Radiation Oncology, Lewis Katz School of Medicine, Temple University, Philadelphia, PA 19140, USA

Full list of author information is available at the end of the article
}

(c) The Author(s). 2018 Open Access This article is distributed under the terms of the Creative Commons Attribution 4.0 International License (http://creativecommons.org/licenses/by/4.0/), which permits unrestricted use, distribution, and reproduction in any medium, provided you give appropriate credit to the original author(s) and the source, provide a link to the Creative Commons license, and indicate if changes were made. The Creative Commons Public Domain Dedication waiver (http://creativecommons.org/publicdomain/zero/1.0/) applies to the data made available in this article, unless otherwise stated. 


\section{Background}

Sepsis is a life-threatening organ dysfunction caused by a dysregulated host response to infection [1]. It is one of the leading causes of death in ICUs causing more than 200,000 deaths/year in the USA [2,3]. Patients who recover from sepsis suffer from impaired quality of life and rapid degradation in cognition and functional capacity which is more pronounced in middle-aged and older survivors [4].

During sepsis, the endothelium is an active participant in the recruitment and activation of neutrophils through the production of chemokines/cytokines and expression of adhesion molecules [5-7]. Sepsis induces activation of cerebral endothelial cell (EC) which initiates a cascade of proinflammatory events by releasing various mediators into the brain [8], resulting in alterations in the bloodbrain barrier (BBB), leukocyte dysregulation, and subsequent brain tissue damage [9]. A key step in neutrophilmediated brain damage is the migration of neutrophils across the damaged $\mathrm{BBB}$. $\mathrm{BBB}$ properties are primarily determined by tight and adherens junctions between the cerebral EC [10]. Normally, junctional complexes prevent the transmigration of blood cells. However, in sepsis, BBB disruption leads to the influx of neutrophils into brain tissue. To date, there are no specific pharmacological therapies available that protect brain from neutrophil-mediated tissue damage $[2,11]$.

Our group has identified protein kinase C-delta (PKCS) as a critical regulator of the inflammatory response and an important regulator of endothelial proinflammatory signaling [12-18]. PKC $\delta$ inhibition had an anti-inflammatory and lung protective effect indicating that targeting PKC $\delta$ may offer a unique therapeutic strategy for the protection of EC and control of neutrophil-induced tissue damage $[16,18]$. PKC $\delta$ is a member of the protein kinase $\mathrm{C}(\mathrm{PKC})$ superfamily. While PKC $\delta$ has been identified as an important regulator of inflammation, the mechanisms by which $\mathrm{PKC} \delta$ regulates $\mathrm{BBB}$ permeability, EC adhesion molecule/junctional protein expression, and neutrophil migration in sepsis are incompletely understood and further studies are needed to elucidate the regulation and relative contribution of PKC $\delta$ in the control of individual steps in this process.

Given the complexity of existing in vivo models of the inflammatory process, several in vitro models have been developed. While 2D flow chambers can be used to examine adhesion molecule/junctional protein expression, as well as neutrophil rolling/adhesion phenomena, they lack the appropriate geometry to model EC permeability/TEER changes and neutrophil transmigration. Boyden/transwell chambers can be used for migration studies, however do not account for in vivo fluid shear and size/topology of microvessels which is essential for the expression of junctional proteins or provide real-time visualization of the above-mentioned events. As there are no models that can monitor all these critical parameters and events in a single assay, the understanding of the inflammation cascade and the development of anti-inflammatory drugs has been hindered. In this study, we have modified our previously developed novel blood-brain barrier on-a-chip $\left(\mathrm{B}^{3} \mathrm{C}\right)$ microfluidic assay [19] so that it resolves and facilitates real-time assessment of the characteristics of the $\mathrm{BBB}$ as well as individual steps including rolling, firm arrest, spreading, and migration of neutrophils into the extravascular tissue space in a single system. This integrated microfluidic assay was then used to study the role of PKC $\delta$ in the modulation of each individual steps involved in inflammation of the brain during sepsis in a realistic microvasculature geometry with physiological shear conditions which allows direct observation and quantification of permeability, protein expression, leukocytes rolling, adhesion, and migration over time.

The objective of this study is to test the hypothesis that inhibition of $\mathrm{PKC} \delta$ prevents activation of EC, protects BBB structural integrity, prevents neutrophil migration, and attenuates the development of brain inflammation. This study will provide important insight into the molecular mechanisms and functional role of PKC $\delta$ in the underlying pathophysiology of brain inflammation during sepsis and will ascertain whether targeting $\mathrm{PKC} \delta$ offers a unique therapeutic strategy for the control of BBB damage in sepsis.

\section{Materials and methods}

\section{Materials, equipment, and reagents}

A rabbit polyclonal anti-rat PKC $\delta$ (Ser643/676) antibody was purchased from Cell Signaling Technology (Beverly, MA). A rabbit polyclonal anti-human TJP1/ Tight Junction Protein 1 antibody was purchased from Boster Biological Technology (Pleasanton, CA); Alexa Fluor $^{\oplus} 568$ goat anti-rabbit polyclonal antibody and Alexa Fluor 488 Phalloindin were purchased from Life Technologies Corporation (Carlsbad, CA). Human fibronectin was obtained from BD Biosciences (San Jose, CA). Human brain microvascular endothelial cell (HBMVEC), human astrocytes, endothelial cell media (ECM), and astrocyte media were purchased from ScienCell (Carlsbad, CA). Subcellular Protein Fractionation Kit, bovine serum albumin (BSA), phosphate buffered saline (PBS), Hanks' Balanced Salt solution (HBSS), Trypsin/EDTA, formalin, Triton X-100, Draq5, 40 kDa Texas Red-conjugated dextran, and Hoechst 33342 were purchased from Thermofisher Scientific (Rockford, IL). Formamide was purchased from MilliporeSigma (Burlington, MA). $\mathrm{B}^{3} \mathrm{C}$ microfluidic assay platform was manufactured at the Synvivo, Inc. (Huntsville, AL). 
A Nikon TE200 fluorescence microscope equipped with an automated stage was used for performing experiments. Images were acquired using an ORCA Flash 4 camera (Hamamatsu Corp., USA). An Olympus FluoView FV1000 confocal microscope equipped with a fully automated stage was used for capturing confocal image stacks. PhD Ultra Syringe pump (Harvard Apparatus, USA) was used for injecting growth media, permeability dye, or neutrophil/microparticle suspension to the $\mathrm{B}^{3} \mathrm{C}$ with high precision. A stage warmer was used to keep the $\mathrm{B}^{3} \mathrm{C}$ at $37{ }^{\circ} \mathrm{C}$. NIS Elements software (Nikon Instruments Inc., Melville, NY) was used to control the microscope stage and the camera.

\section{Synthesis of PKC $\delta$-TAT inhibitor peptide}

A peptide antagonist (PKC $-\mathrm{TAT}$ ) was synthesized to selectively inhibit PKC $\delta$ activity. The peptide, derived from the first unique region (V1) of PKC $\delta$ (SFNSYELGSL: amino acids 8-17), was coupled to a membrane-permeant peptide sequence in the HIV TAT gene product (YGRKKRRQRRR: amino acids 47-57 of TAT) via an $\mathrm{N}$-terminal Cys-Cys bond [20]. The resulting PKC $\delta$-TAT peptide produces a unique dominant-negative phenotype that effectively inhibits activation of PKC $\delta$ but not other PKC isotypes. The PKC $\delta$-TAT inhibitory peptide was synthesized by Mimotopes (Melbourne, Australia) and purified to $>95 \%$ by HPLC.

\section{In vivo sepsis model}

Animal procedures and handling were conducted in accordance with the NIH standards and were approved by the Institutional Animal Care and Use Committee at Temple University. Male Sprague-Dawley rats (300$350 \mathrm{~g}$ ) (Charles River, Boston, MA) were used in all experiments. Rats were acclimated for at least 1 week in a climate-controlled facility and given free access to food and water. Sepsis was induced by the cecal ligation and puncture (CLP) method as described previously [21, 22]. Briefly, a midline laparotomy was performed and the cecum identified, the mesentery trimmed, and the stalk joining the cecum to the large intestine was ligated. The cecum was punctured with a 21-gauge needle, stool expressed and the cecum returned to the abdomen, and the incision closed in two layers. Sham controls underwent a laparotomy without cecal ligation or puncture. Following CLP or sham surgery, the abdominal incision was closed, and the animals were orally intubated with a 16-gauge intravenous cannula and randomized to receive either the PKC $\delta$-TAT inhibitory peptide $(200 \mu \mathrm{g} / \mathrm{kg}$ in $200 \mu \mathrm{l}$ of PBS) or a like volume of PBS (vehicle).

\section{PKC $\delta$ phosphorylation and translocation in rats}

At $24 \mathrm{~h}$ post-surgery, animals were euthanized and the brains were harvested. Cell membrane and cytoplasm fractions of brain tissue were isolated using a Subcellular Protein Fractionation Kit for Tissues. For Western blot analysis, isolated tissue samples were mixed with $2 \mathrm{X}$ sample buffer to a final concentration of $30 \mu \mathrm{g} / \mathrm{lane}$ and heated for $5 \mathrm{~min}$ at $95^{\circ} \mathrm{C}$. Purity of membrane and cytosolic fractions were routinely monitored by probing cell membrane marker VE-cadherin. Proteins were separated on 4-12\% SDS-PAGE gels and transferred to nitrocellulose membranes for blotting. The presence of phosphorylated PKC $\delta$ in membrane and cytoplasm fractions was determined by a phospho-specific PKC $\delta$ (Ser643/676) antibody [23-25]. PKC $\delta$ membrane translocation was then quantified by densitometry analysis to Western blot films in ImageJ software, and the values were expressed as a ratio of membrane fraction density to cytosolic fraction density.

\section{Permeability measurements in vivo}

Twenty-four hours post-sham or CLP surgery, animals were anesthetized, and Evans blue dye (4\% in saline) was given at $2 \mathrm{ml} / \mathrm{kg}$ via tail vein. Thirty minutes post-dye injection, each rat was perfused with $50 \mathrm{ml}$ of saline by direct injection through left ventricle into the ascending aorta. Brain samples were then collected, weighed, and homogenized in PBS. Evans blue was extracted from tissue homogenates by incubating samples in formamide at $60{ }^{\circ} \mathrm{C}$ for $14-18 \mathrm{~h}$. The concentration of Evans blue in brain homogenate supernatants was quantified by a dual wavelength spectrophotometric method at absorptions of 620 and $740 \mathrm{~nm}$ that allows for correction of contaminating heme pigments using the following formula:

$$
E 620(\text { corrected })=E 620-(1.426 \times E 740+0.030)
$$

Data are expressed as micrograms per milligram brain weight.

\section{Design and fabrication of the $\mathrm{B}^{3} \mathrm{C}$ microfluidic assay}

The blood-brain barrier on a chip $\left(\mathrm{B}^{3} \mathrm{C}\right)$ microfluidic assay used in this study (Fig. 1) is based on a modification of our previous design [19]. Vascular channels as well as tissue compartment were reproduced on a glass slide using soft-lithography processes as reported previously $[19,26]$. This $\mathrm{B}^{3} \mathrm{C}$ microfluidic assay consists of vascular channels, which were covered with human brain microvascular endothelial cells (HBMVEC), in connection with a tissue compartment via a porous barrier. Microfabricated pillars (10 $\mu \mathrm{m}$ diameter) were used to fabricate the $3 \mu \mathrm{m} \times 100 \mu \mathrm{m}$ pores resulting in vascular channels connected to a tissue compartment via $3 \mu \mathrm{m}$ porous barrier, which is the optimum size for neutrophil migration. 


\section{Culturing of endothelial cells in $B^{3} C$}

HBMVEC and human astrocytes were cultured in their corresponding culture media and used between passages 1 and 2. The astrocyte-conditioned media (ACM) was prepared by culturing $10^{7}$ astrocytes in $75 \mathrm{~cm}^{2}$ culture flask with $12 \mathrm{ml}$ of growth media for $48 \mathrm{~h}$, after which the media were collected and filtered as reported previously [27]. The collected ACM was mixed with fresh $\mathrm{ECM}$ at 50/50 ratio and was used as the culture media for $\mathrm{EC}$ in $\mathrm{B}^{3} \mathrm{C}$. Before $\mathrm{EC}$ seeding, the $\mathrm{B}^{3} \mathrm{C}$ was first degassed, washed with sterile deionized water, and then coated with human fibronectin at $37^{\circ} \mathrm{C}$ for $30 \mathrm{~min}$ to facilitate cell attachment. HBMVEC suspended in ECM at a concentration of $5 \times 10^{6}$ cells $/ \mathrm{ml}$ were seeded into the $\mathrm{B}^{3} \mathrm{C}$ using a programmable syringe pump and incubated at $37{ }^{\circ} \mathrm{C}$ for $4 \mathrm{~h}$ prior to shear flow $(0.1 \mu \mathrm{l} / \mathrm{min}$ at the entry of the network) for $48 \mathrm{~h}$. HBMVEC in $\mathrm{B}^{3} \mathrm{C}$ formed a confluent lumen and aligned in the direction of flow (Fig. 1). Formation of the 3D lumen in vascular channels under physiological conditions was confirmed using confocal microscopy $[19,28]$. Assays in which neutrophils freely entered the tissue compartment without attachment were discarded.

\section{Permeability and transendothelial electrical resistance measurements in $B^{3} C$}

HBMVEC integrity in the vascular channels was quantified by measuring the flux of a $40-\mathrm{kDa}$ Texas Red fluorescent dextran $(25 \mu \mathrm{M}$ in ECM) from the vascular to the tissue compartment. The vascular channels were connected to a Hamilton gas-tight syringe filled with dextran solution maintained at $37{ }^{\circ} \mathrm{C}$ mounted on a programmable syringe pump. The $\mathrm{B}^{3} \mathrm{C}$ was then mounted on a Nikon TE200 fluorescence microscope equipped with a temperature controllable automated stage. Permeability was measured by imaging the $\mathrm{B}^{3} \mathrm{C}$ every minute for $2 \mathrm{~h}$ while the dextran solution flowed through the vascular channel (flow rate $0.1 \mu \mathrm{l} /$ min). Using our previously published method $[19,27]$, the following equation was used to calculate permeability $(\mathrm{P})$ of dextran across the endothelium in $\mathrm{B}^{3} \mathrm{C}$ :

$$
P=\frac{1}{I_{\mathrm{v}_{0}}} \frac{V}{S} \frac{d I_{\mathrm{t}}}{d t}
$$

where $I_{t}$ is the average intensity in the tissue compartment, $I_{v_{0}}$ is the maximum fluorescence intensity of the vascular channel, and $\frac{V}{S}$ is the ratio of vascular channel volume to its surface area.

Transendothelial electrical resistance (TEER) was measured following our established method [19] using an electrode compartment outside the vascular channels. $\mathrm{Ag} / \mathrm{AgCl}$ electrodes were placed on either side of the HBMVEC in the vascular and tissue compartments and connected to SynVivo Cell Resistance Analyzer (SynVivo Inc., Huntsville, AL). Impedance measurements were acquired at $10 \mathrm{kHz}$ with a voltage of $10 \mathrm{mV}$. Baseline TEER of the confluent EC monolayer
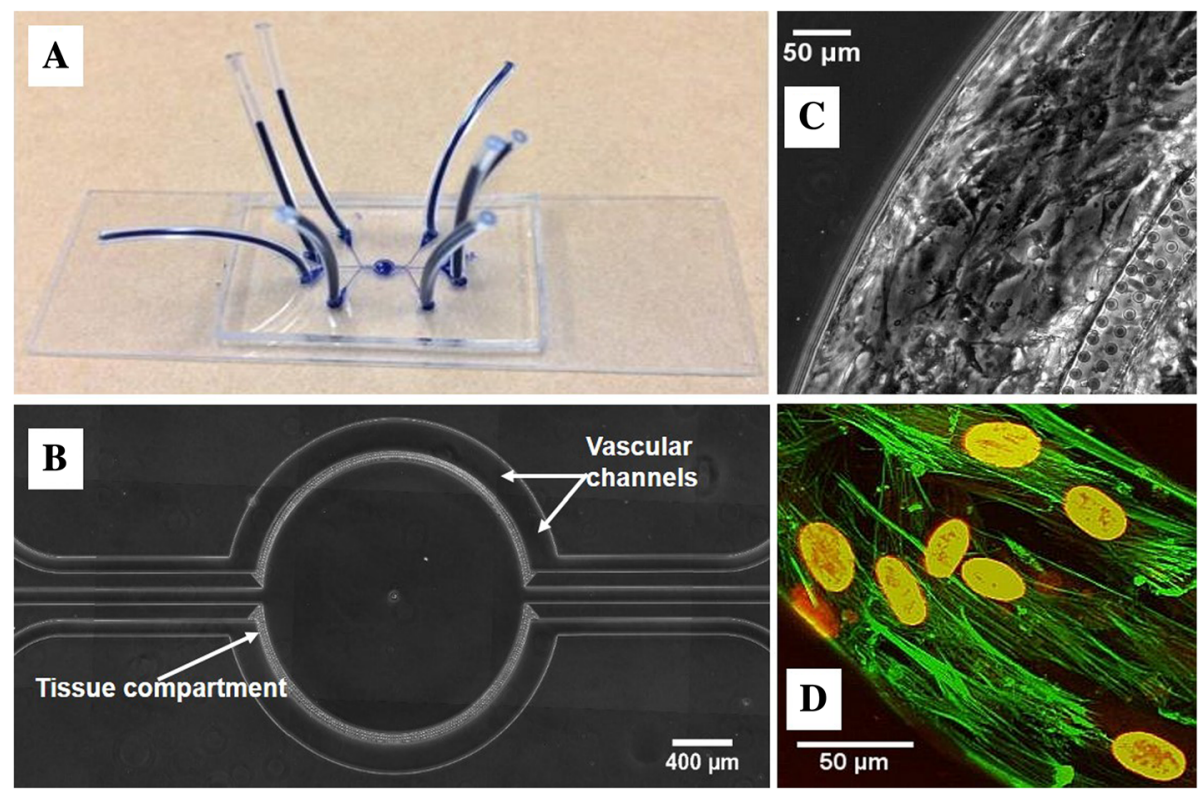

Fig. 1 HBMVEC cultured under flow in the vascular channel of $B^{3} C$ form a complete lumen. The $B^{3} C$ is assembled on a microscope glass slide (a) with plastic tubes (dark blue) allowing access to individual vascular channels and the tissue compartment (b). Magnified (c) view shows HBMVEC were cultured to confluence in the vascular channels. 3D reconstruction of confocal images (d) of HBMVEC stained with f-actin (green) and Draq5 (red) after $72 \mathrm{~h}$ of flow culture $(0.1 \mu \mathrm{l} / \mathrm{min})$ 
was determined and then at 0,24 , and $48 \mathrm{~h}$ following the addition of TNF- $\alpha$.

\section{Neutrophil adhesion and migration in $\mathrm{B}^{3} \mathrm{C}$}

Following informed consent, human heparinized blood was obtained from healthy male or female adult donors. Human neutrophils were isolated by ficoll-hypaque separation, dextran sedimentation, and hypotonic lysis to remove erythrocytes $[21,23]$. Isolated neutrophils were suspended in HBSS $\left(5 \times 10^{6}\right.$ cells $\left./ \mathrm{ml}\right)$ and labeled using CFDA/SE probe for $10 \mathrm{~min}$ at room temperature. All procedures were approved by the Temple University Institutional Review Board (Philadelphia, PA, USA).

Neutrophils were introduced into the vascular channels of the $\mathrm{B}^{3} \mathrm{C}$ at a flow rate of $0.1 \mu \mathrm{l} / \mathrm{min}$. Neutrophils in contact with EC that did not move for $30 \mathrm{~s}$ were considered adherent. Adhesion level of neutrophils to the endothelium reached steady state after $10 \mathrm{~min}$ of flow and was quantified by scanning the entire network [28]. The number of migrated neutrophils was quantified using time-lapse imaging every $3 \mathrm{~min}$ for $60 \mathrm{~min}$.

\section{Immunofluorescence staining of the EC in $\mathrm{B}^{3} \mathrm{C}$}

To study morphological changes in cells, actin filaments were stained with phalloidin and cell nucleus was stained with Hoechst 33342. To examine EC barrier function after sepsis with or without $\mathrm{PKC} \delta-i$ treatment, the formation of endothelial cell-to-cell tight junction was characterized using immunostaining against zonula occludens-1 (ZO-1). Briefly, the $\mathrm{B}^{3} \mathrm{C}$ was perfused with $4 \%$ neutral buffered formalin to fix the cells followed by 10 -min treatment with $0.1 \%$ Triton X-100 to expose ZO-1 protein. After blocking with $5 \%$ goat serum in PBS for $1 \mathrm{~h}$ at $37{ }^{\circ} \mathrm{C}$, the vascular channel of the $\mathrm{B}^{3} \mathrm{C}$ was incubated with mouse monoclonal primary antibody against ZO-1 (1:100) overnight at $4{ }^{\circ} \mathrm{C}$. On the second day, the $\mathrm{B}^{3} \mathrm{C}$ was then incubated with fluorophore-conjugated secondary antibodies Alexa fluor 594 goat anti-mouse IgG for $1 \mathrm{~h}$ at $37{ }^{\circ} \mathrm{C}$. Cells in $\mathrm{B}^{3} \mathrm{C}$ were washed with $\mathrm{PBS}$ containing $5 \%$ serum between each step using a syringe. Images were taken using the same microscope and camera system as described before. The background noise was removed from the image by thresholding, and the ZO-1 staining was enhanced in the ImageJ software using the "Find Edges" function.

\section{PKC $\delta$ phosphorylation and translocation in HBMVEC}

The presence and subcellular distribution of phosphorylated PKC $\delta$ in HBMVEC was determined by immunostaining followed by fluorescence imaging. PKC $\delta$ phosphorylation was quantified by intensity analysis in ImageJ software, and the values were expressed as a ratio of cell nucleus intensity to cytosolic intensity. HBMVEC cultured in chamber slides were fixed with
$4 \%$ neutral buffered formalin followed by $0.1 \%$ Triton X-100 permeabilization. After blocking with $5 \%$ goat serum in PBS for $1 \mathrm{~h}$ at $37{ }^{\circ} \mathrm{C}$, HBMVEC were incubated with phospho-specific PKC $\delta$ (Ser643/676) antibody $(1: 100)$ overnight at $4{ }^{\circ} \mathrm{C}$. On the second day, the cells were washed and then incubated with Alexa fluor 594 fluorescent goat anti-rabbit secondary antibody for $1 \mathrm{~h}$ at $37^{\circ} \mathrm{C}$. Cells were washed with PBS containing $5 \%$ serum between each step. Images were taken using the same microscope and camera system as described before.

\section{Data analysis}

Nikon Elements and Fiji software were used to collect and analyze the data [29]. Data are presented as mean \pm SEM. Statistical significance was determined by one-way or two-way analysis of variance (ANOVA) with TukeyKramer post hoc using SigmaPlot software. Differences were considered statistically significant if $p<0.05$.

\section{Results}

\section{Brain EC form a complete lumen in $\mathrm{B}^{3} \mathrm{C}$}

The schematic of the $\mathrm{B}^{3} \mathrm{C}$ microfluidic assay is shown in Fig. 1a. Two independent vascular channels with dimensions of $200 \mu \mathrm{m}$ (width) $\times 100 \mu \mathrm{m}$ (height) $\times 2762 \mu \mathrm{m}$ (length) were placed around the tissue compartment. The dimensions of the vascular channels which closely approximate the size and morphology of microvessels in vivo permit the $\mathrm{B}^{3} \mathrm{C}$ to maintain physiologically relevant shear flow conditions for HBMVEC growth (Fig. 1c). Simultaneous real-time visualization of the vascular and tissue compartments was achieved by the side-by-side placement of optically clear polydimethylsiloxane (PDMS) onto a glass slide. The vascular channels and tissue compartment were separated by a porous interface which was constructed by a tightly packed cylindrical micro-pillar array to allow for biochemical and cellular communications. Previously, we have reported that brain EC barrier function was dependent on the presence of astrocytes or ACM [19]. Moreover, no significant differences were detected in EC permeability, TEER, or ZO-1 expression when comparing EC treated with ACM vs. EC co-cultured with astrocytes [19]. Therefore, in this study, HBMVEC was cultured with ACM in the vascular channels without astrocytes in the tissue compartment. To allow for real-time monitoring of EC barrier function as well as neutrophil-endothelial interaction, the $\mathrm{B}^{3} \mathrm{C}$ is constructed from optically clear PDMS assembled on a microscope slide (Fig. 1b). HBMVEC cultured with ACM under flow formed a complete 3D lumen in the vascular channels (Fig. 1d), which mimics the normal EC lining observed in vivo. 
Sepsis-induced PKC $\delta$ activation and BBB barrier damage in rats are attenuated by treatment with a PKC $\delta$ peptide inhibitor

PKC反 activation requires phosphorylation on key serine/threonine sites, and translocation of PKC $\delta$ from the cell cytosol to membrane sites is a critical step in the activation of PKC $\delta$ in brain inflammation [23, 30]. To demonstrate that sepsis leads to PKC $\delta$ activation in the rat brain, we performed Western blot analysis on the subcellular fractionation of brain homogenates. As shown in Fig. 2a, in sham-operated rats, the majority of phosphorylated $\mathrm{PKC} \delta$ was located in the cytosolic fraction as compared to the membrane fraction. In contrast, at $24 \mathrm{~h}$ post-CLP surgery, there was a significant increase in translocation of PKC $\delta$ from the cytosolic site to the membrane site. The PKC $\delta$ translocation pattern in CLP rats treated with the PKC $\delta-i$ was similar to that of sham-operated animals, indicating that the PKC $\delta$ activity was inhibited in treated animals. Densitometric analysis (Fig. 2b) of the Western blot images demonstrated that PKC $\delta$ translocation in septic rat brains was significantly increased and that treatment of septic animals with $\mathrm{PKC} \delta-i$ inhibited this translocation. This pattern of $\mathrm{PKC} \delta$ phosphorylation is consistent with our in vivo observations where $\mathrm{PKC} \delta$ inhibition significantly reduced sepsis-induced Evans blue extravasation into the brain tissue at $24 \mathrm{~h}$ post-CLP surgery (Fig. 2c).

Inflammation-mediated activation of PKC $\delta$ in HBMVEC is inhibited by treatment with a PKC $\delta$ peptide inhibitor

To examine the effect of inflammation on PKC $\delta$ activation in brain endothelial cells, we determined PKC $\delta$ phosphorylation by immunostaining of HBMVEC in culture. As shown in Fig. 3a, in response to TNF treatment, there was a significant increase in $\mathrm{PKC} \delta$ phosphorylation and enzyme translocation as compared to cells treated with buffer alone (no treatment). The addition of the PKC $\delta$ peptide inhibitor (TNF- $\alpha+$ PKC $\delta-i$ ) attenuated TNF-mediated phosphorylation and translocation of PKC $\delta$. This observation was confirmed by fluorescence intensity analysis as shown in Fig. 3b.

\section{PKC $\delta$ inhibition modulates increased permeability in activated HBMVEC in $\mathrm{B}^{3} \mathrm{C}$}

In vitro, the HBMVEC permeability was quantified in the $\mathrm{B}^{3} \mathrm{C}$ with no treatment or $4 \mathrm{~h}$ after TNF- $\alpha$ with or without PKC $\delta-i$ treatment. As shown in Fig. 4a, a threefold increase was observed in dextran permeability from vascular channels to the tissue compartment in TNF- $\alpha$-treated HBMVEC $\left(3.7 \pm 1.0 \times 10^{-7}\right.$ to $\left.12.8 \pm 0.7 \times 10^{-7} \mathrm{~cm} / \mathrm{s}\right)$. Significant reduction in dextran permeability was observed when TNF- $\alpha$-activated HBMVEC $\left(5.3 \pm 0.8 \times 10^{-7} \mathrm{~cm} / \mathrm{s}\right)$ were treated with the PKC $\delta$ - $i$.

\section{PKC $\delta$ inhibition modulates TEER decrease in activated HBMVEC in $\mathrm{B}^{3} \mathrm{C}$}

Our microfluidic system has electrodes in the two compartments for TEER measurements. Under static conditions, TEER of HBMVEC remained relatively constant over $96 \mathrm{~h}$ at $50 \mathrm{k} \Omega$ (data not shown). Under shear flow conditions, tight junctional endothelial integrity was significantly enhanced and TEER values increased by more than twofold $(108.6 \pm 4.0 \mathrm{k} \Omega)$. Addition of TNF- $\alpha$ produced a significant decrease in TEER indicating decreased EC barrier, whereas treatment with $\mathrm{PKC} \delta-i$ of TNF- $\alpha$-activated HBMVEC modulated this decrease to the control level $(116.7 \pm 5.4 \mathrm{k} \Omega$ ) (Fig. 4b).

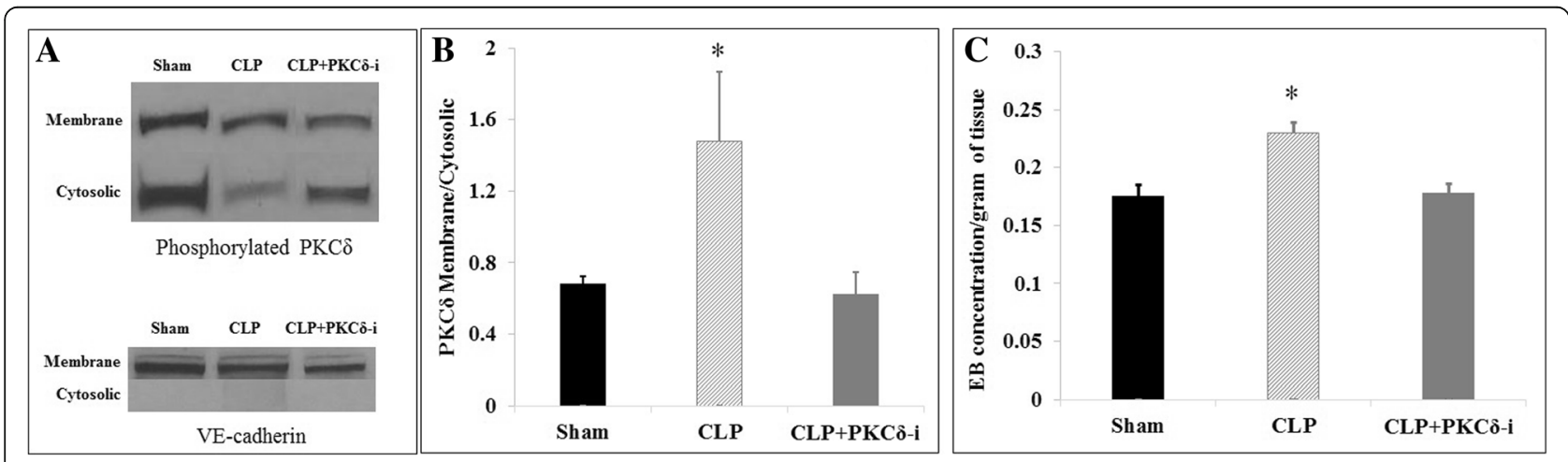

Fig. 2 Sepsis-induced PKC $\delta$ activation and BBB barrier damage in rats are attenuated by PKC $\delta$ inhibition. a Representative Western blot images of phosphor-PKC $\delta$ membrane and cytosolic fractions in the brain samples of sham-operated, septic (CLP), or treated septic (CLP+PKC $-i)$ rats. VEcadherin was used as a marker for the membrane fraction. b Densitometry analysis of phosphorylated PKC $\delta$ (Ser643) translocation. Values are expressed as the density ratio of the membrane to the cytosolic fraction. c PKC $\delta$ inhibition (PKC $\delta-i)$ also attenuates sepsis (CLP) induced Evans blue (EB) dye extravasation in rat brain. Data are presented as mean \pm SEM $(n=3)$. ${ }^{*} p<0.05$ compared to sham and CLP+PKC $\delta-i$ by ANOVA with Tukey-Kramer post hoc 


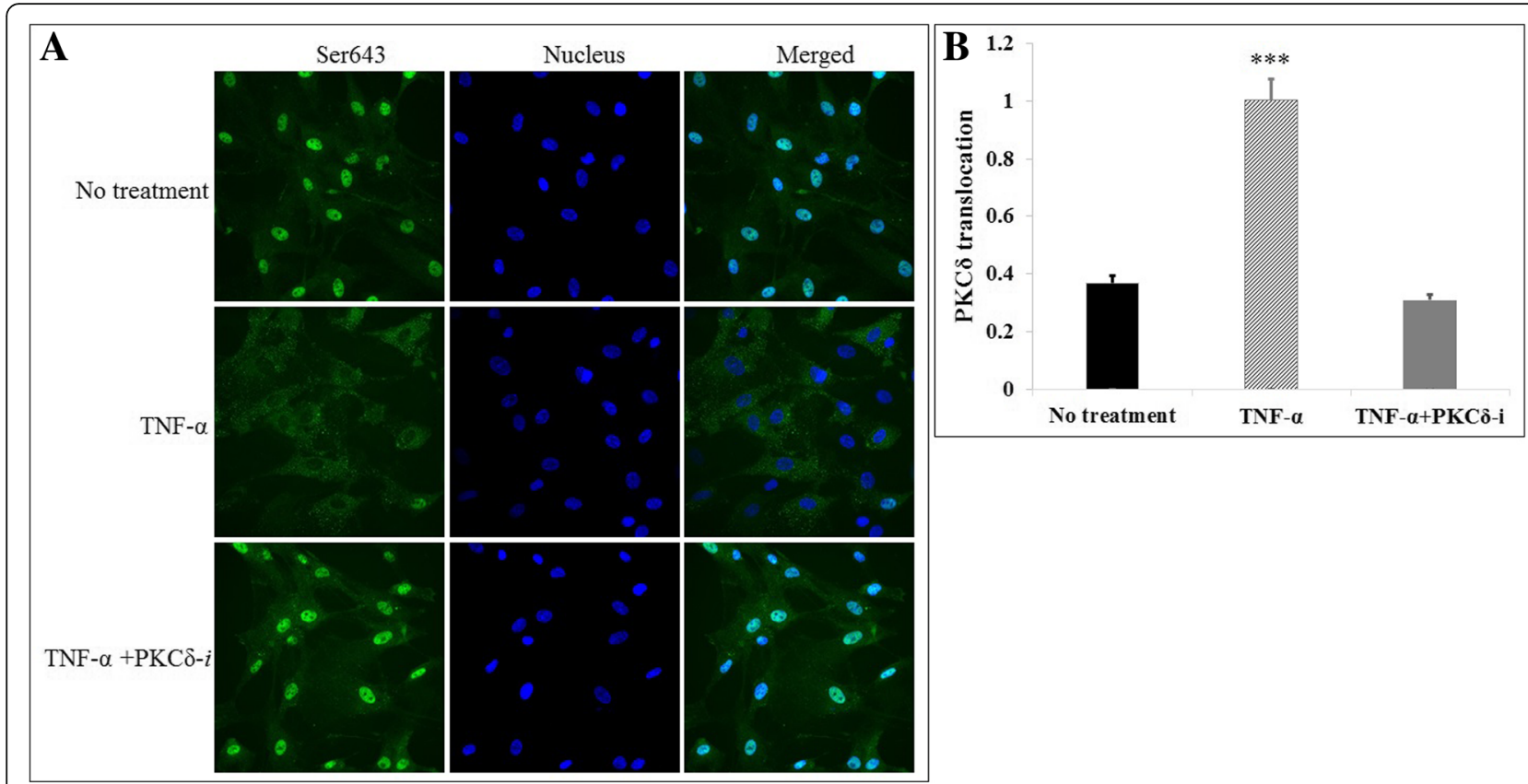

Fig. 3 Cytokine-induced PKC $\delta$ phosphorylation in vitro is attenuated by PKC $\delta$ inhibition. a Representative immunostaining images of phosphorPKC $\delta$ distribution in non-treated, TNF-a-activated, or TNF-a + PKC $\delta$ - - -treated HBMVEC in static culture. $\mathbf{b}$ Fluorescence intensity analysis of phosphorylated PKC $\delta$ (Ser643) translocation. Values are expressed as the intensity ratio of the cell nucleus to the cytosol. Data are presented as mean \pm SEM $(n=3) .{ }^{* * *} p<0.0001$ compared to no treatment and TNF-a + PKC $-i$ by ANOVA with Tukey-Kramer post hoc

\section{PKC $\delta$ inhibition attenuates neutrophil adhesion and migration in $\mathrm{B}^{3} \mathrm{C}$}

To further explore the effect of PKC $\delta$ inhibition on neutrophil-endothelial cell interaction during sepsis, neutrophil adhesion to and migration across HBMVEC under shear flow was investigated. Cytokine activation ( 4 h TNF- $\alpha$ treatment) significantly increased the number of adhering neutrophils to ECs as compared to controls ( $77 \pm 7$ vs. $199 \pm 10$ ). PKC inhibition significantly reduced the total number of adhered neutrophils by $54 \%$, a level which is not statistically different from control levels (77 \pm 7 vs. $91 \pm 16$ ) (Fig. 5a).

Neutrophil migration across HBMVEC into the tissue compartment was used to further assess endothelial barrier function after cytokine activation with or without PKC $\delta$ inhibition. In $\mathrm{B}^{3} \mathrm{C}$, the number of migrated neutrophils across TNF- $\alpha$-activated endothelium in response to the chemoattractant (fMLP) significantly increased over $60 \mathrm{~min}$. Neutrophil migration across cytokine-activated
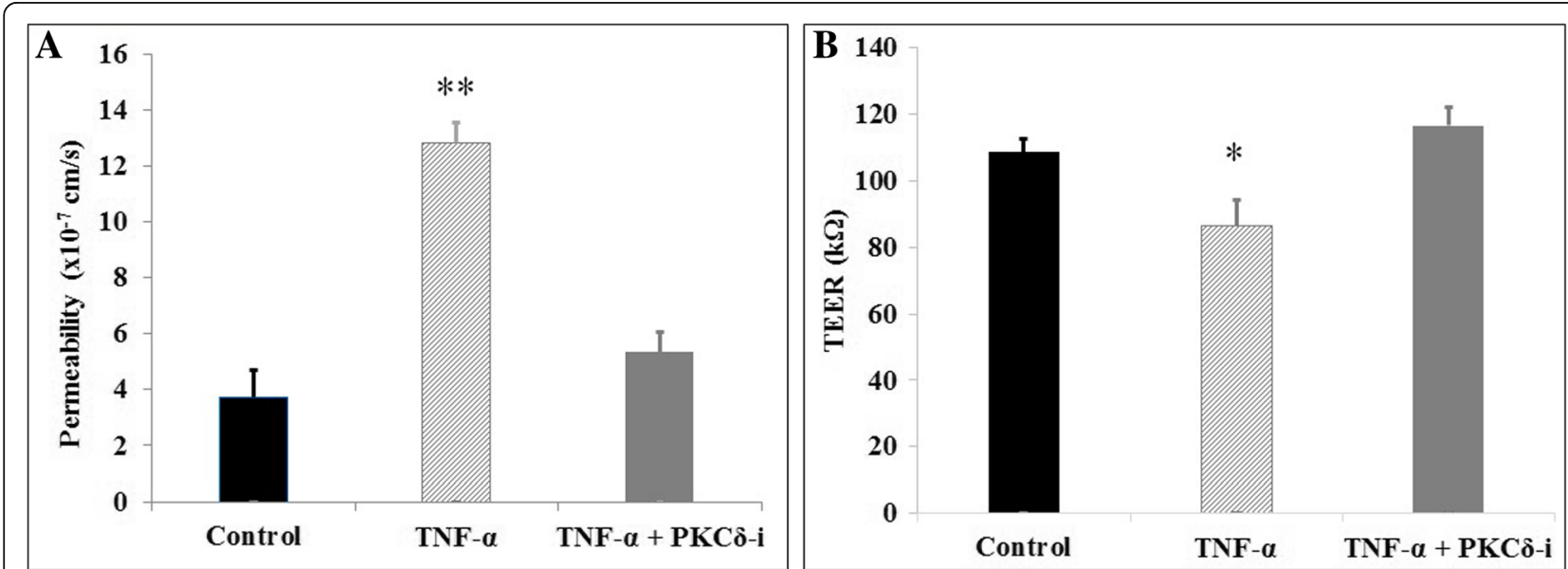

Fig. 4 PKC inhibition (PKC $\delta-i)$ attenuates TNF-a-induced permeability increase (a) and TEER decrease (b) in vitro in $B^{3} C$ after $4 \mathrm{~h}$ of TNF-a activation. Data are presented as mean $\pm \operatorname{SEM}(n=3) .{ }^{*} p<0.01,{ }^{*} p<0.05$, compared to control and TNF-a + PCK $-i$ treatment group by ANOVA with TukeyKramer post hoc 


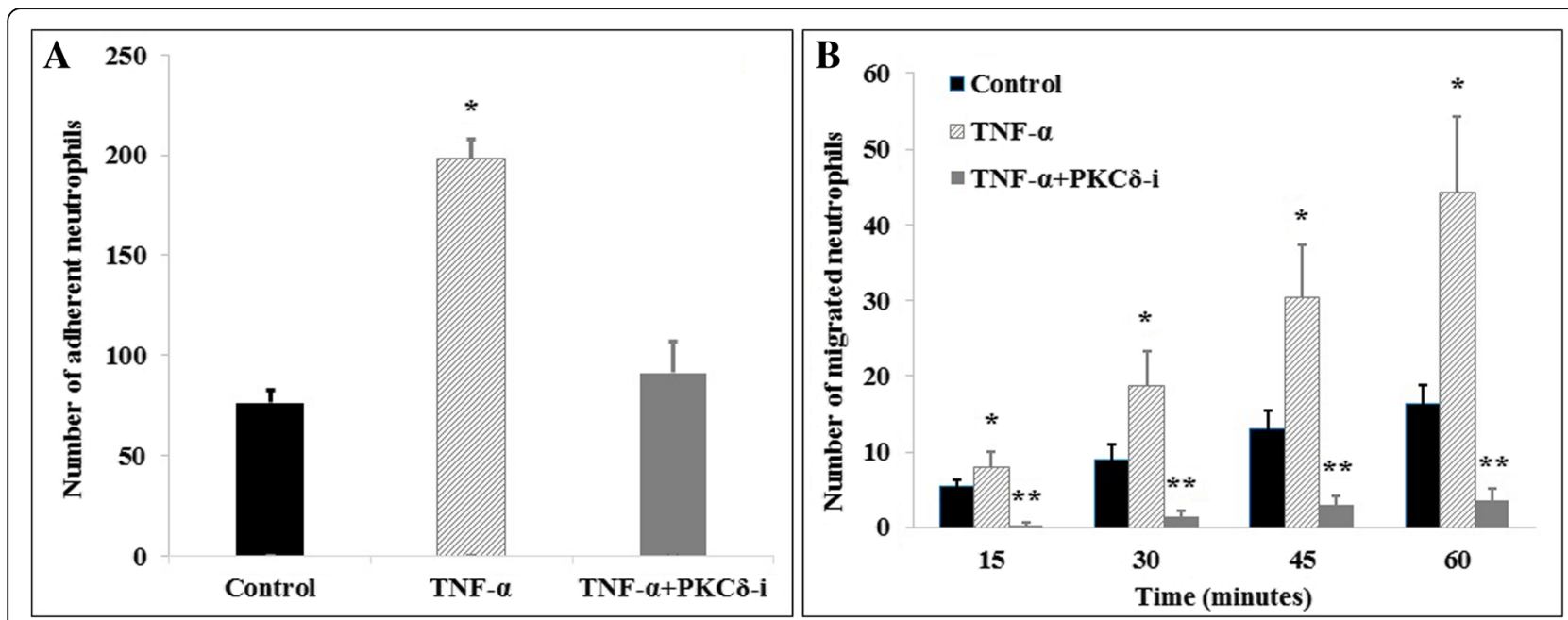

Fig. 5 PKC inhibition (PKC $-i)$ reduces neutrophil adhesion (a) and migration $(\mathbf{b})$ in $\mathrm{B}^{3} \mathrm{C}$ in vitro. Data are presented as mean $\pm \operatorname{SEM}(n=3) .{ }^{* *} p<0.01$, ${ }^{*} p<0.05$ compared to the other two groups by ANOVA with Tukey-Kramer post hoc

HBMVEC was almost completely inhibited after PKC $\delta$ TAT treatment (Fig. 5b), making it significantly lower than the control level of neutrophil migration.

\section{PKC $\delta$ inhibition attenuates cytokine-induced tight junction damage in $\mathrm{B}^{3} \mathrm{C}$}

Tight junctions are important for regulating the barrier properties of BBB. Immunofluorescence staining for ZO-1 was used to highlight HBMVEC tight junction molecule expression under control conditions, after treatment with TNF- $\alpha$, or treatment with TNF- $\alpha$ and PKC $\delta$-TAT inhibitor (Fig. 6). Under control conditions, HBMVEC continuously expressed tight junctions when cultured using HA-conditioned media under shear flow in $\mathrm{B}^{3} \mathrm{C}$ as indicated by strong continuous ZO-1 staining in the vascular compartment (Fig. 6q). This shows that our $\mathrm{B}^{3} \mathrm{C}$ assay not

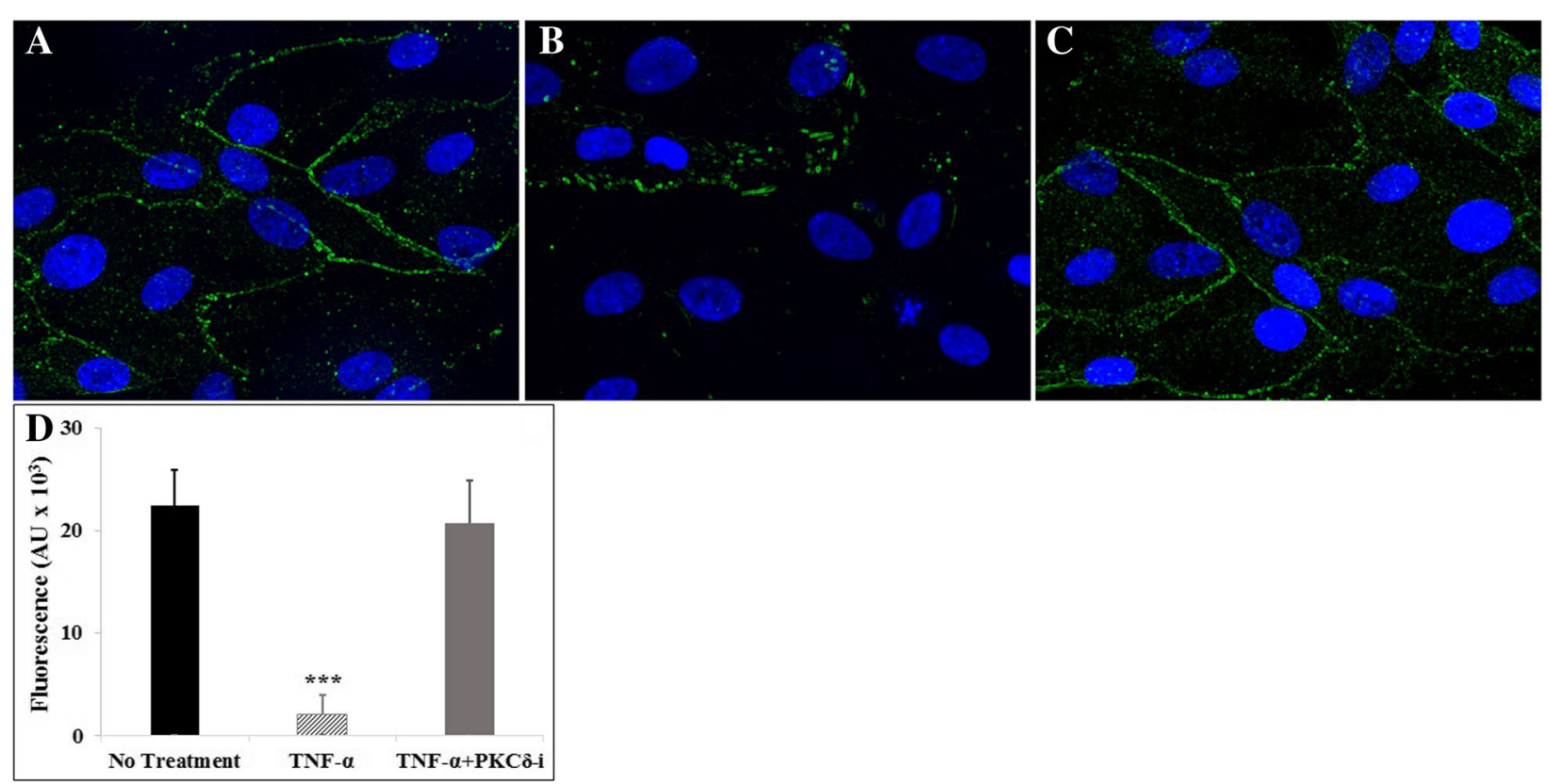

Fig. 6 Tight junction formation by HBMVEC under flow conditions as indicated by immunofluorescence staining of ZO-1. PKC inhibition (PKC $\delta-i)$ attenuates TNF-a-induced tight junction damage in vitro in $B^{3} \mathrm{C}$. When cultured with normal media, tight junctions were fully established between adjacent cells (a). Tight junction expression was disrupted after $4 \mathrm{~h}$ of TNF-a activation (b), while PKC $\delta$ inhibition (TNF- $a+$ PKC $\delta-i)$ restored tight junction expression (c). HBMVEC cultured for $72 \mathrm{~h}$ under flow $(0.1 \mu \mathrm{l} / \mathrm{min}$ ) were stained with ZO-1 (red) and Hoechst 33342 (blue). d Quantitative analysis to the total tight junction fluorescence intensity confirmed our observation. Data are presented as mean \pm SEM $(n=3)$. ${ }^{* * *} p<0.001$ compared to no treatment and TNF- $a+$ PKC $\delta-i$ by ANOVA with Tukey-Kramer post hoc 
only provides an in vivo-like shear flow environment, but also permits junction formation in ECs cultured in the vascular compartment. TNF- $\alpha$ activation significantly downregulated tight junction expression as indicated by a lack of ZO-1 in some cells as well as intermittent ZO-1 expression along the edges of the remaining cells (Fig. 6b). The expression of ZO-1 in PKC $\delta$-TAT-treated, TNF- $\alpha$-activated HBMVEC (Fig. 6c) was similar to those observed in control ECs (Fig. 6a), indicating that PKC $\delta$ inhibition attenuates cytokine activation-induced tight junction damage. This observation was confirmed by quantitative analysis to the total tight junction fluorescence intensity (Fig. 6d).

\section{Discussion}

The inflammatory response is composed of multiple overlapping and redundant mechanisms, and recent research has shifted the focus to developing therapeutics that can regulate common control signaling points which are activated by diverse signals. In vitro studies using our bioinspired microfluidic assay (bMFA) demonstrated a role for pulmonary endothelial $\mathrm{PKC} \delta$ in mediating neutrophilendothelial interaction [28]. Studies also suggest that PKC $\delta$ may be a major mediator and/or modulator of inflammatory responses in brain [31,32], suggesting a critical role of PKC $\delta$ in mediating BBB damage during sepsis. In this study, we demonstrate that activation of PKC $\delta$ results in alterations in tight junction protein expression and functional integrity of the BBB after cytokine activation or CLP-induced sepsis. In vitro, inhibition of PKC $\delta$ prevented activation of ECs, protected BBB structure integrity, and prevented neutrophil migration across the brain EC. Treatment of septic animals with the PKC $\delta$ inhibitor prevented activation of $\mathrm{PKC} \delta$ and restored $\mathrm{BBB}$ permeability to control levels. Our findings support the hypothesis that PKC $\delta$ inhibition can attenuate the disruption of ZO-1 tight junction protein, resulting in a decrease in permeability and an increase in electrical resistance across the endothelial cell barrier.

Maintenance of normal brain function is very much dependent on the integrity of BBB that is highly selective to the passage of molecules and cells from the blood to the brain tissue. Extravasation of dyes and changes in transendothelial electrical resistance are often used to measure permeability of the BBB barrier in vivo and in vitro. For example, Evans blue is widely regarded as the standard measurement of BBB permeability and its extravasation has been used by numerous studies to quantify BBB breakdown in vivo [33-37], despite some reported limitations [38-40]. Transport of macromolecules larger than $5 \mathrm{~nm}$, such as the $40-\mathrm{kDa}$ dextran, occurs through the transcellular pathway (through the cell body regulated by the cell membrane lipid bilayer) [4144] that is regulated in part by cytoskeleton proteins such as actin and is altered by TNF- $\alpha$ activation [45]. Under pathological conditions such as cytokine stimulations, the distribution of junctions between endothelial cells, as well as cytoskeleton proteins such as actin, can be downregulated resulting in paracellular transport of macromolecules. TNF- $\alpha$ stimulation has been shown to induce alterations in cell-cell and cell-matrix interaction [45]. Components of adherens (cadherin) and tight junctions (occludins) were found to be downregulated in TNF- $\alpha$ stimulated cells and the contacts between neighboring cells were breached [46-50]. TEER on the other hand is an index of current flow via the paracellular route (through the junctions between cells and regulated by junctional proteins) and via the transcellular route [51]. These different regulatory mechanisms may become more prominent depending on the phenomenon being studied. In this study, TNF- $\alpha$ activation had a larger impact on $\mathrm{BBB}$ permeability to a $40-\mathrm{kDa}$ dextran (threefold increase) as compared to TEER (23\% reduction) indicating a shift from transcellular to paracellular transport.

The role of $\mathrm{PKC}$ in the regulation of $\mathrm{BBB}$ has been studied in several disease conditions in vivo [52-55]. However, the relative contribution of each of the different PKC isoforms is still not clear. To date, there are at least 12 different PKC isoforms discovered [56]. Conflicting data on the critical role of PKC $\delta$ in these diseases have been described. For example, three PKC family isotypes (PKC $\alpha, P K C \delta$, and $\mathrm{PKC \varepsilon}$ ) were found to be co-localized with $\mathrm{EC}$ after blast exposure [52]. However, high levels of PKC $\theta$, РКCל, and $\mathrm{PKC} Y$ isozyme expression were seen in cortical endothelial cells in a rat hypoxia and post-hypoxic reoxygenation model [54]. In a rat hypertension model, sustained pharmacological inhibition of PKC $\delta$ prevented the development of hypertensive encephalopathy through prevention of BBB breakdown [55]. Utilizing an in vitro transwell co-culture model of the BBB of mouse bEnd. 3 cells, Kim et al. demonstrated that both PKC $\beta I I$ and PKC $\delta$ were activated during aglycemic hypoxia and while PKC $\delta$ activation was found to be protective of BBB integrity, PKC $\beta I$ activation was detrimental to $\mathrm{BBB}$ integrity [53]. Thus, whereas these studies have shown the potential role of PKC in barrier permeability, there is still some uncertainty about the specific role of the $\delta$ isoform. The differential regulation of BBB by PKC $\delta$ in diverse cell systems is not surprising as specific regulatory roles for PKC $\delta$ are context specific and dependent on mechanisms of PKC $\delta$ activation, phosphorylation patterns, and input from other signaling pathways $[23,57,58]$. To our knowledge, the present study is the first to provide direct evidence of $\mathrm{BBB}$ disruption caused by PKC $\delta$ activation in sepsis. Meanwhile, no studies have examined the effects of PKC $\delta$ inhibition as a therapeutic approach for treatment of sepsisinduced brain damage. 
Previous studies from our group demonstrated a key role for PKC $\delta$ in the regulation of proinflammatory signaling controlling the activation and recruitment of neutrophils $[14,16,18,28,59,60]$. Our recent study using a PKC $\delta$ Knock-in mouse model of sepsis and an in vitro biomimetic microfluidic assay further demonstrated that PKC $\delta$ activation (tyrosine 155 phosphorylation) is required for neutrophil activation, adherence, and transmigration through pulmonary endothelium [61]. Consistent with these findings, in the current study, we show that PKC $\delta$ not only plays a significant role in regulating EC permeability, TEER, and tight junction protein expression in activated HBMVEC in the absence of neutrophils, but also inhibits neutrophil-endothelial cell interaction.

A novel aspect of this study is assessment of vascular integrity using a biomimetic blood-brain barrier microfluidic platform $\left(\mathrm{B}^{3} \mathrm{C}\right)$ where EC permeability and TEER as well as neutrophil transmigration can be directly evaluated. Compared to traditional transwell-based BBB models, the permeability of our $\mathrm{B}^{3} \mathrm{C}$ model was significantly lower and more closely mimic reported in vivo values [19]. More importantly, $\mathrm{B}^{3} \mathrm{C}$ allowed for real-time monitoring of neutrophil-endothelial interaction under physiologically relevant flow conditions.

\section{Conclusions}

We developed a first dynamic in vitro $\mathrm{BBB}$ on-a-chip $\left(\mathrm{B}^{3} \mathrm{C}\right)$ that offers the flexibility of real-time analysis and is suitable for studies of BBB function as well as screening of novel therapeutics. Our findings suggest that PKC $\delta$ activation is a key signaling event that dysregulates the structural and functional integrity of BBB, which leads to vascular damage and inflammation-induced tissue damage due to neutrophil transmigration. Our data suggest that PKC $\delta$-TAT has therapeutic potential for the prevention or reduction of cerebrovascular injury in sepsis-induced vascular damage. Utilizing both in vivo (rat CLP model) and in vitro $\left(\mathrm{B}^{3} \mathrm{C}\right)$ tools, our findings support a novel therapeutic paradigm that targets PKC $\delta$ and neutrophil-endothelial interactions to protect BBB integrity and attenuate sepsis-induced brain tissue damage. These findings highlight an important control point of the proinflammatory signaling cascade and potential therapeutic targets for the treatment of sepsisinduced brain vascular damage.

\footnotetext{
Abbreviations

ACM: Astrocyte-conditioned media; ANOVA: Analysis of variance; $\mathrm{B}^{3} \mathrm{C}$ : Bloodbrain barrier on-a-chip; BBB: Blood-brain barrier; bMFA: Bioinspired microfluidic assay; BSA: Bovine serum albumin; CFDA/SE: Carboxyfluorescein diacetate succinimidyl ester; CLP: Cecal ligation and puncture; EC: Endothelial cell; ECM: Endothelial cell media; fMLP: N-Formylmethionyl-leucyl-phenylalanine; HBMVEC: Human brain microvascular endothelial cell; HBSS: Hanks' Balanced Salt solution; PBS: Phosphate buffered saline; PDMS: Polydimethylsiloxane; PKC: Protein kinase C; PKC 8 : Protein kinase C-delta; PKC $\delta$-i: Protein kinase Cdelta TAT peptide inhibitor; TEER: Transendothelial electrical resistance; TNFa: Tumor necrosis factor a; ZO-1: Zonula occludens-1
}

\section{Acknowledgements}

Not applicable.

\section{Funding}

This work was supported by the American Heart Association (16GRNT29980001) and National Institutes of Health (GM114359 and HL111552).

\section{Availability of data and materials \\ All data generated or analyzed during this study are included in this published article.}

\section{Authors' contributions}

YT and FS performed the research, analyzed the data, and wrote the manuscript and were also responsible for the statistical analyses. SS and EL performed the CLP surgery and Western blot. JCL and QY performed, edited, and analyzed the imaging and analysis tools. YT, LEK, and MFK designed the study, organized the experiments, analyzed the data, and wrote the manuscript. All authors read and approved the final manuscript.

\section{Ethics approval and consent to participate}

All experiments were conducted with the approval of the Institutional Animal Care and Use Committee of Temple University School of Medicine.

The use of human subjects adhered to National Institutes of Health guidelines and was approved by the Institutional Review Board at Temple University School of Medicine. Written informed consent was obtained from all participants.

\section{Consent for publication}

Not applicable.

\section{Competing interests}

L.E.K. is listed as an inventor on US Patent \#8,470,766, entitled "Novel Protein Kinase C Therapy for the Treatment of Acute Lung Injury," which is assigned to the Children's Hospital of Philadelphia and the University of Pennsylvania.

\section{Publisher's Note}

Springer Nature remains neutral with regard to jurisdictional claims in published maps and institutional affiliations.

\section{Author details}

${ }^{1}$ Department of Mechanical Engineering, College of Engineering, Temple University, Philadelphia, PA 19122, USA. ${ }^{2}$ Center for Inflammation, Clinical and Translational Lung Research, Lewis Katz School of Medicine, Temple University, Philadelphia, PA 19140, USA. ${ }^{3}$ Sol Sherry Thrombosis Research Center, Lewis Katz School of Medicine, Temple University, Philadelphia, PA 19140, USA. ${ }^{4}$ Department of Radiation Oncology, Lewis Katz School of Medicine, Temple University, Philadelphia, PA 19140, USA.

Received: 9 July 2018 Accepted: 22 October 2018

Published online: 06 November 2018

\section{References}

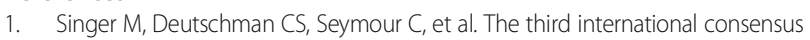
definitions for sepsis and septic shock (sepsis-3). JAMA. 2016;315:801-10.

2. Deutschman Clifford S, Tracey Kevin J. Sepsis: current dogma and new perspectives. Immunity. 2014;40:463-75.

3. Angus DC, van der Poll T. Severe sepsis and septic shock. N Engl J Med. 2013;369:840-51.

4. Leibovici L. Long-term consequences of severe infections. Clin Microbiol Infect. 2013;19:510-2.

5. Goldenberg NM, Steinberg BE, Slutsky AS, Lee WL. Broken barriers: a new take on sepsis pathogenesis. Sci Transl Med. 2011;3:88ps25.

6. Maniatis NA, Orfanos SE. The endothelium in acute lung injury/acute respiratory distress syndrome. Curr Opin Crit Care. 2008;14:22-30. https://doi. org/10.1097/MCC.1090b1013e3282f1269b1099.

7. Danese S, Dejana E, Fiocchi C. Immune regulation by microvascular endothelial cells: directing innate and adaptive immunity, coagulation, and inflammation. J Immunol. 2007;178:6017-22.

8. Handa O, Stephen J, Cepinskas G. Role of endothelial nitric oxide synthasederived nitric oxide in activation and dysfunction of cerebrovascular 
endothelial cells during early onsets of sepsis. Am J Physiol Heart Circ Physiol. 2008;295:H1712-9.

9. Sonneville R, Verdonk F, Rauturier C, Klein IF, Wolff M, Annane D, Chretien F, Sharshar T. Understanding brain dysfunction in sepsis. Ann Intensive Care. 2013;3:15.

10. Stamatovic SM, Keep RF, Andjelkovic AV. Brain endothelial cell-cell junctions: how to "open" the blood brain barrier. Curr Neuropharmacol. 2008;6:179-92.

11. Iskander KN, Osuchowski MF, Stearns-Kurosawa DJ, Kurosawa S, Stepien D, Valentine C, Remick DG. Sepsis: multiple abnormalities, heterogeneous responses, and evolving understanding. Physiol Rev. 2013;93:1247-88.

12. Kilpatrick LE, Lee JY, Haines KM, Campbell DE, Sullivan KE, Korchak HM. A role for PKC-delta and PI 3-kinase in TNF-alpha-mediated antiapoptotic signaling in the human neutrophil. Am J Physiol Cell Physiol. 2002;283:C48-57.

13. Kilpatrick LE, Sun S, Korchak HM. Selective regulation by delta-PKC and PI 3kinase in the assembly of the antiapoptotic TNFR-1 signaling complex in neutrophils. Am J Physiol Cell Physiol. 2004;287:C633-42.

14. Kilpatrick LE, Sun S, Mackie D, Baik F, Li H, Korchak HM. Regulation of TNF mediated antiapoptotic signaling in human neutrophils: role of \{delta\}-PKC and ERK1/2. J Leuk Biol. 2006;80:1512-21.

15. Liverani E, Mondrinos MJ, Sun S, Kunapuli SP, Kilpatrick LE. Role of Protein Kinase C-delta in regulating platelet activation and platelet-leukocyte interaction during sepsis. PLoS One. 2018;13:e0195379.

16. Kilpatrick LE, Standage SW, Li H, Raj NR, Korchak HM, Wolfson MR, Deutschman CS. Protection against sepsis-induced lung injury by selective inhibition of protein kinase C- $\delta$ ( $\delta$-PKC). J Leukoc Biol. 2011;89:3-10,

17. Mondrinos MJ, Kennedy PA, Lyons M, Deutschman CS, Kilpatrick LE. Protein kinase $C$ and acute respiratory distress syndrome. Shock. 2013;39:467-79.

18. Mondrinos MJ, Zhang T, Sun S, Kennedy PA, King DJ, Wolfson MR, Knight LC, Scalia R, Kilpatrick LE. Pulmonary endothelial protein kinase C-Delta (PKCS) regulates neutrophil migration in acute lung inflammation. Am J Pathol. 2014;184:200-13.

19. Deosarkar SP, Prabhakarpandian B, Wang B, Sheffield JB, Krynska B, Kiani MF. A novel dynamic neonatal blood-brain barrier on a chip. PLoS One. 2015:10:e0142725

20. Chen L, Hahn H, Wu G, Chen CH, Liron T, Schechtman D, Cavallaro G, Banci L, Guo Y, Bolli R, et al. Opposing cardioprotective actions and parallel hypertrophic effects of delta PKC and epsilon PKC. Proc Natl Acad Sci U S A. 2001:98:11114-9.

21. Mondrinos MJ, Zhang T, Sun S, Kennedy PA, King DJ, Wolfson MR, Knight LC, Scalia R, Kilpatrick LE. Pulmonary endothelial protein kinase C-delta (PKCdelta) regulates neutrophil migration in acute lung inflammation. Am J Pathol. 2014;184:200-13.

22. Mondrinos MJ, Knight LC, Kennedy PA, Wu J, Kauffman M, Baker ST, Wolfson $M R$, Kilpatrick LE. Biodistribution and efficacy of targeted pulmonary delivery of a protein kinase C-delta inhibitory peptide: impact on indirect lung injury. J Pharmacol Exp Ther. 2015;355:86-98.

23. Kilpatrick LE, Sun S, Li H, Vary TC, Korchak HM. Regulation of TNF-induced oxygen radical production in human neutrophils: role of delta-PKC. J Leukoc Biol. 2010;87:153-64

24. Begley R, Liron T, Baryza J, Mochly-Rosen D. Biodistribution of intracellularly acting peptides conjugated reversibly to Tat. Biochem Biophys Res Commun. 2004;318:949-54

25. Vary TC, Goodman S, Kilpatrick LE, Lynch CJ. Nutrient regulation of PKCepsilon is mediated by leucine, not insulin, in skeletal muscle. Am J Physiol Endocrinol Metab. 2005:289:E684-94.

26. Prabhakarpandian B, Shen M-C, Pant K, Kiani MF. Microfluidic devices for modeling cell-cell and particle-cell interactions in the microvasculature. Microvasc Res. 2011;82:210-20.

27. Tang Y, Soroush F, Sheffield JB, Wang B, Prabhakarpandian B, Kiani MF. A biomimetic microfluidic tumor microenvironment platform mimicking the EPR effect for rapid screening of drug delivery systems. Sci Rep. 2017:7:9359.

28. Soroush F, Zhang T, King DJ, Tang Y, Deosarkar S, Prabhakarpandian B, Kilpatrick LE, Kiani MF. A novel microfluidic assay reveals a key role for protein kinase $C$ delta in regulating human neutrophil-endothelium interaction. J Leukoc Biol. 2016;100:1027-35.

29. Schindelin J, Arganda-Carreras I, Frise E, Kaynig V, Longair M, Pietzsch T, Preibisch S, Rueden C, Saalfeld S, Schmid B, et al. Fiji: an open-source platform for biological-image analysis. Nat Methods. 2012;9:676-82.

30. Salzer E, Santos-Valente E, Keller B, Warnatz K, Boztug K. Protein kinase C delta: a gatekeeper of immune homeostasis. J Clin Immunol. 2016; 36:631-40.
31. Gordon R, Anantharam V, Kanthasamy AG, Kanthasamy A. Proteolytic activation of proapoptotic kinase protein kinase Cdelta by tumor necrosis factor alpha death receptor signaling in dopaminergic neurons during neuroinflammation. J Neuroinflammation. 2012;9:82.

32. Kaasinen SK, Goldsteins G, Alhonen L, Janne J, Koistinaho J. Induction and activation of protein kinase $\mathrm{C}$ delta in hippocampus and cortex after kainic acid treatment. Exp Neurol. 2002;176:203-12.

33. Wang Z, Li Y, Cai S, Li R, Cao G. Cannabinoid receptor 2 agonist attenuates blood-brain barrier damage in a rat model of intracerebral hemorrhage by activating the Rac1 pathway. Int J Mol Med. 2018;42:2914-22.

34. Li T, Xu W, Gao L, Guan G, Zhang Z, He P, Xu H, Fan L, Yan F, Chen G. Mesencephalic astrocyte-derived neurotrophic factor affords neuroprotection to early brain injury induced by subarachnoid hemorrhage via activating Akt-dependent prosurvival pathway and defending bloodbrain barrier integrity. FASEB J. 0:fi.201800227RR.

35. Kucuk M, Ugur Yilmaz C, Orhan N, Ahishali B, Arican N, Elmas I, Gurses C, Kaya M. The effects of lipopolysaccharide on the disrupted blood-brain barrier in a rat model of preeclampsia. J Stroke Cerebrovasc Dis. 2018.

36. Sarami Foroshani M, Sobhani ZS, Mohammadi MT, Aryafar M. Fullerenol nanoparticles decrease blood-brain barrier interruption and brain edema during cerebral ischemia-reperfusion injury probably by reduction of interleukin-6 and matrix metalloproteinase-9 transcription. J Stroke Cerebrovasc Dis. 2018;27:3053-65.

37. Faezi M, Nasseri Maleki S, Aboutaleb N, Nikougoftar M. The membrane mesenchymal stem cell derived conditioned medium exerts neuroprotection against focal cerebral ischemia by targeting apoptosis. J Chem Neuroanat. 2018:94:21-31.

38. Wang HL, Lai TW. Optimization of Evans blue quantitation in limited rat tissue samples. Sci Rep. 2014;4:6588.

39. Saunders NR, Dziegielewska KM, Mollgard K, Habgood MD. Markers for blood-brain barrier integrity: how appropriate is Evans blue in the twentyfirst century and what are the alternatives? Front Neurosci. 2015;9:385.

40. Yao L, Xue X, Yu P, Ni Y, Chen F. Evans blue dye: a revisit of its applications in biomedicine. Contrast Media Mol Imaging. 2018;2018:7628037.

41. Sukriti S, Tauseef M, Yazbeck P, Mehta D. Mechanisms regulating endothelial permeability. Pulm Circ. 2014:4:535-51.

42. Vogel SM, Malik AB. Cytoskeletal dynamics and lung fluid balance. Compr Physiol. 2012:2:449-78.

43. Komarova Y, Malik AB. Regulation of endothelial permeability via paracellular and transcellular transport pathways. Annu Rev Physiol. 2010;72:463-93.

44. Predescu SA, Predescu DN, Palade GE. Endothelial transcytotic machinery involves supramolecular protein-lipid complexes. Mol Biol Cell. 2001; 12:1019-33.

45. Seynhaeve AL, Vermeulen CE, Eggermont AM, ten Hagen TL. Cytokines and vascular permeability: an in vitro study on human endothelial cells in relation to tumor necrosis factor-alpha-primed peripheral blood mononuclear cells. Cell Biochem Biophys. 2006:44:157-69.

46. Coyne CB, Vanhook MK, Gambling TM, Carson JL, Boucher RC, Johnson LG. Regulation of airway tight junctions by proinflammatory cytokines. Mol Biol Cell. 2002;13:3218-34.

47. Wachtel M, Bolliger MF, Ishihara H, Frei K, Bluethmann H, Gloor SM. Downregulation of occludin expression in astrocytes by tumour necrosis factor (TNF) is mediated via TNF type-1 receptor and nuclear factor-kappaB activation. J Neurochem. 2001:78:155-62.

48. Mankertz J, Tavalali S, Schmitz H, Mankertz A, Riecken EO, Fromm M, Schulzke JD. Expression from the human occludin promoter is affected by tumor necrosis factor alpha and interferon gamma. J Cell Sci. 2000;113(Pt 11):2085-90.

49. Kniesel $\mathrm{U}$, Wolburg H. Tight junctions of the blood-brain barrier. Cell Mol Neurobiol. 2000;20:57-76.

50. Wright TJ, Leach L, Shaw PE, Jones P. Dynamics of vascular endothelialcadherin and beta-catenin localization by vascular endothelial growth factor-induced angiogenesis in human umbilical vein cells. Exp Cell Res. 2002;280:159-68.

51. Benson K, Cramer S, Galla HJ. Impedance-based cell monitoring: barrier properties and beyond. Fluids Barriers CNS. 2013;10:5.

52. Lucke-Wold BP, Logsdon AF, Smith KE, Turner RC, Alkon DL, Tan Z, Naser ZJ Knotts CM, Huber JD, Rosen CL. Bryostatin-1 restores blood brain barrier integrity following blast-induced traumatic brain injury. Mol Neurobiol. 2015; 52:1119-34. 
53. Kim YA, Park SL, Kim MY, Lee SH, Baik EJ, Moon CH, Jung YS. Role of PKCbetall and PKCdelta in blood-brain barrier permeability during aglycemic hypoxia. Neurosci Lett. 2010;468:254-8.

54. Willis CL, Meske DS, Davis TP. Protein kinase $\mathrm{C}$ activation modulates reversible increase in cortical blood-brain barrier permeability and tight junction protein expression during hypoxia and posthypoxic reoxygenation. J Cereb Blood Flow Metab. 2010;30:1847-59.

55. Qi X, Inagaki K, Sobel RA, Mochly-Rosen D. Sustained pharmacological inhibition of deltaPKC protects against hypertensive encephalopathy through prevention of blood-brain barrier breakdown in rats. J Clin Invest. 2008;118:173-82.

56. Yuan SY. Protein kinase signaling in the modulation of microvascular permeability. Vasc Pharmacol. 2002;39:213-23.

57. Steinberg SF. Distinctive activation mechanisms and functions for protein kinase Cdelta. Biochem J. 2004;384:449-59.

58. Chari R, Getz T, Nagy B Jr, Bhavaraju K, Mao Y, Bynagari YS, Murugappan S, Nakayama K, Kunapuli SP. Protein kinase C[delta] differentially regulates platelet functional responses. Arterioscler Thromb Vasc Biol. 2009;29: 699-705.

59. Kilpatrick LE, Sun S, Li H, Vary TC, Korchak HM. Regulation of TNF-induced oxygen radical production in human neutrophils: role of $\delta$-PKC. J Leukoc Biol. 2010;87:153-64

60. Mondrinos MJ, Knight LC, Kennedy PA, Wu J, Kauffman M, Baker ST, Wolfson $M R$, Kilpatrick LE. Biodistribution and efficacy of targeted pulmonary delivery of a protein kinase C- $\delta$ inhibitory peptide: impact on indirect lung injury. J Pharmacol Exp Ther. 2015:355:86-98.

61. Soroush F, Tang Y, Guglielmo K, Engelmann A, Liverani E, Langston J, Sun S, Kunapuli S, Kiani MF, Kilpatrick LE. Protein kinase C-delta (PKCdelta) tyrosine phosphorylation is a critical regulator of neutrophil-endothelial cell interaction in inflammation. Shock 9000. Publish Ahead of Print.

Ready to submit your research? Choose BMC and benefit from:

- fast, convenient online submission

- thorough peer review by experienced researchers in your field

- rapid publication on acceptance

- support for research data, including large and complex data types

- gold Open Access which fosters wider collaboration and increased citations

- maximum visibility for your research: over $100 \mathrm{M}$ website views per year

At $\mathrm{BMC}$, research is always in progress.

Learn more biomedcentral.com/submissions 